\title{
'Rear elevation' and other stories: re-excavating presence in O.G.S. Crawford's photographs of the 1939 Sutton Hoo excavation
}

\author{
Beth Hodgett
}

O.G.S. Crawford was not only a prominent archaeologist, but also an active photographer who prioritised this relatively new medium in archaeological reserach. This article examines archival images taken by Crawford during the 1939 Sutton Hoo excavation, on the eve of its eightieth anniversary.

Keywords: Sutton Hoo, O.G.S. Crawford, photography, Anastasius Dish

\section{Introduction}

In John Preston's (2007) novelisation of the 1939 excavation of Sutton Hoo, O.G.S. Crawford is an absent presence, due to arrive at any minute but never actually materialising. Crawford's role is minimised not only in fictional accounts of the excavation, but also in factual records; in 1975, Bruce-Mitford wrote that Crawford spent "three working days at the site" and took a total of 64 photographs (1975: 137). In reality, Crawford was present for five working days, arriving on the evening of the $24^{\text {th }}$ and leaving on the afternoon of the $29^{\text {th }}$ of July, and his negative register shows that he took 124 photographs during this time. In 2011, following the discovery of a cache of photographs taken by Mercie Lack and Barbara Wagstaff, newspapers reported that "prior to these photos emerging there were just 29 known pictures of the excavation" (The Telegraph 2011). Furthermore, although three of Crawford's photographs feature in a current display of the Sutton Hoo finds in room 41 at the British Museum, Crawford himself is not credited as the photographer.

Crawford's absence in the above scenarios can be understood through the lens of a much wider discussion about the politics of representation in archaeological fieldwork. Several commentators have highlighted the deliberate erasure of archaeologists in excavation records (McFadyen 1997; McFadyen et al. 1997; Lucas 2001; Shepherd 2003; Baird 2017; Riggs 2017). Specific forms of archaeological labour are subject to different kinds of erasure; photography, for example, is only rarely captured by another camera (Riggs 2017: 362). This is often coupled with the assumption, espoused by Ingold (2011) and Bohrer (2011), that to work with a camera is to somehow put aside one's subjective experience and function outside of the social circumstances of fieldwork. This treatment of archaeological photography disembodies and erases archaeologists such as Crawford, dislocating them both from their work and the social aspects of excavation. In this paper I highlight some of the many ways

* Department of History, Classics \& Archaeology, Birkbeck, University of London, Malet Street, Bloomsbury, London WC1E 7HX, UK (Email: beth.hodgett@prm.ox.ac.uk) 


\section{Beth Hodgett}

in which Crawford's photographs may be argued to reveal presence rather than absence, and social engagement rather than scientific detachment. In doing so I draw upon a collection of 124 prints made and annotated by Crawford, and currently housed in the Oxford Institute of Archaeology.

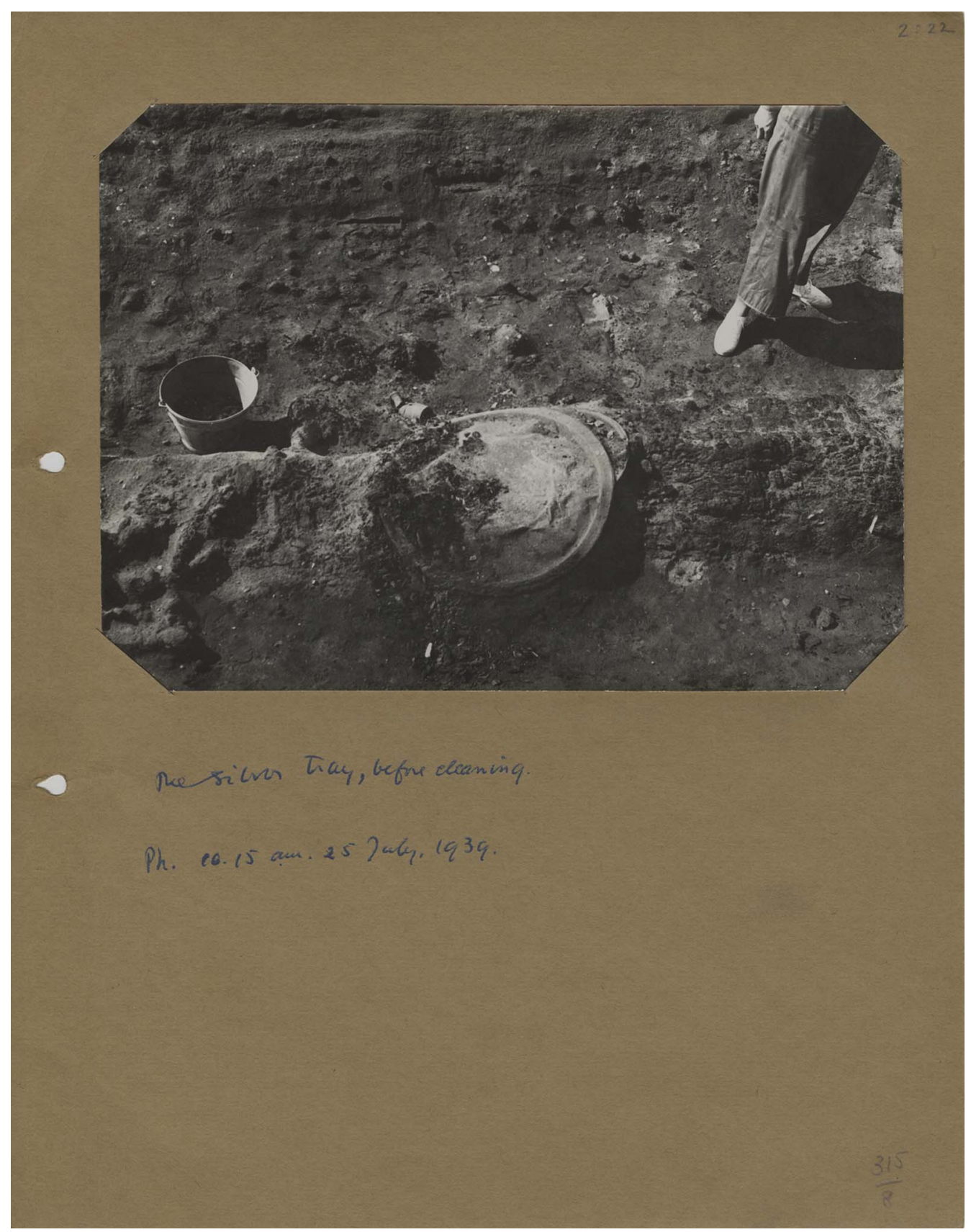

Figure 1. The Anastasius Dish and disembodied foot of Peggy Piggott (print 2.22).

(C) Antiquity Publications Ltd, 2019 


\section{Photographing the finds}

When reviewing Crawford's accounts of the excavation, it is notable that one object in particular seems to dominate his recollections: a silver dish measuring about three feet in diameter. Crawford described the lifting of the dish as "one of the great moments none of us who were present will ever forget" (1940: 2). It is perhaps not surprising that the Anastasius Dish is the centrepiece of the first photograph taken by Crawford at Sutton Hoo (Figure 1). The copy of the print held by the Institute of Archaeology is mounted on brown card, on which Crawford has written "The silver tray, before cleaning. Ph.10:15 am. 25 July 1939". This note was most probably made in the 1950s, when Crawford began to consolidate his photographs in preparation for their donation to the Ashmolean Museum. Yet, on the reverse of the print, another note hidden by the cardboard mount reads "First photo taken" (Figure 2). The tension between these inscriptions, the outward facing recital of factual data for a scholarly audience, and the hidden note tying the photograph to subjective experience resonates throughout the wider sequence of Crawford's photographs of Sutton Hoo.

Traces of Crawford's experience can be found not only in individual prints, but by examining the temporal and spatial relationships between sequences of photographs. Immediately after photographing the Anastasius Dish, Crawford raced from the north side of the trench to the south-west corner to photograph what was exposed of the Bronze Bowls, before careering

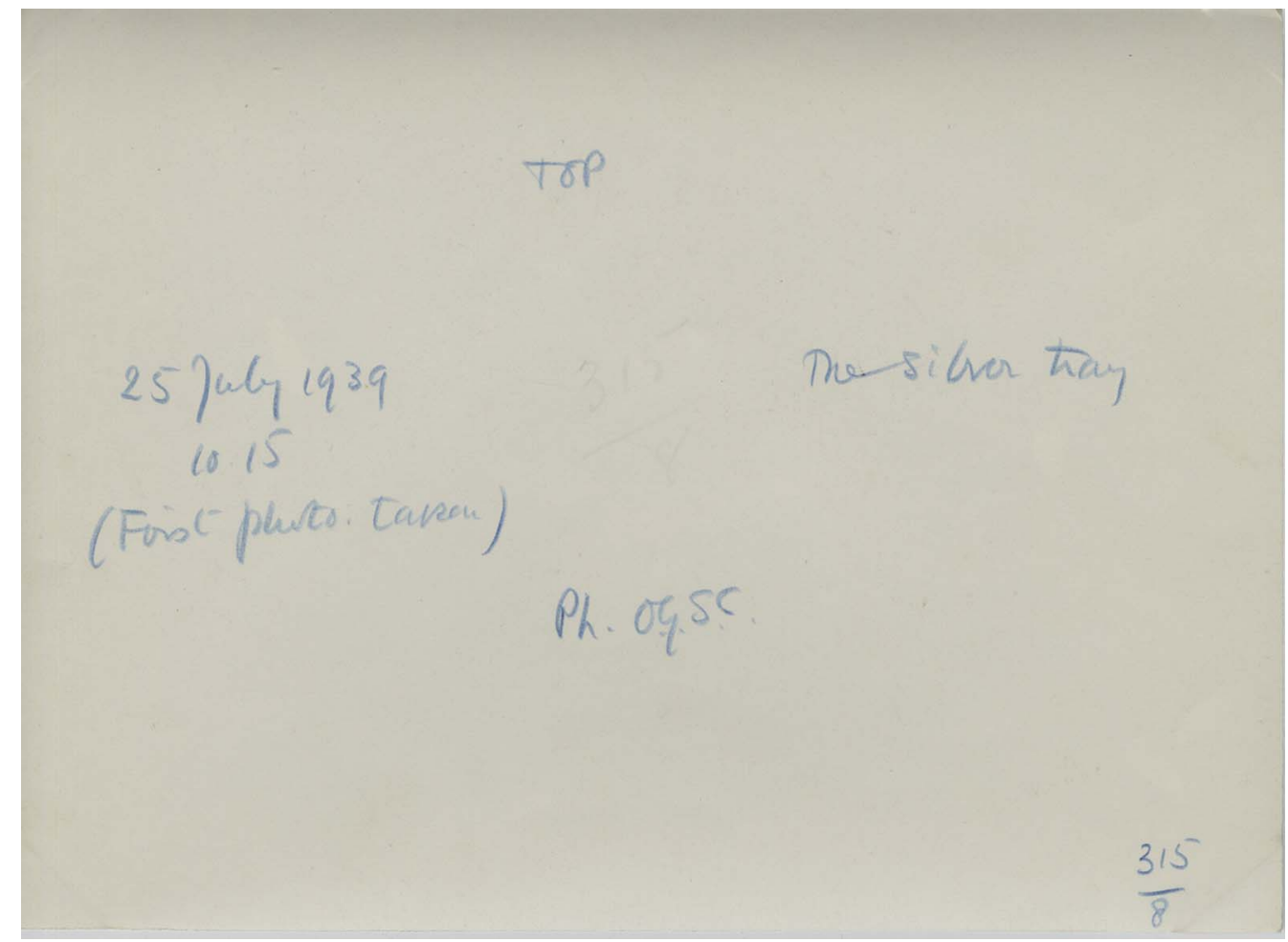

Figure 2. Note on the reverse of print 2.22 . 

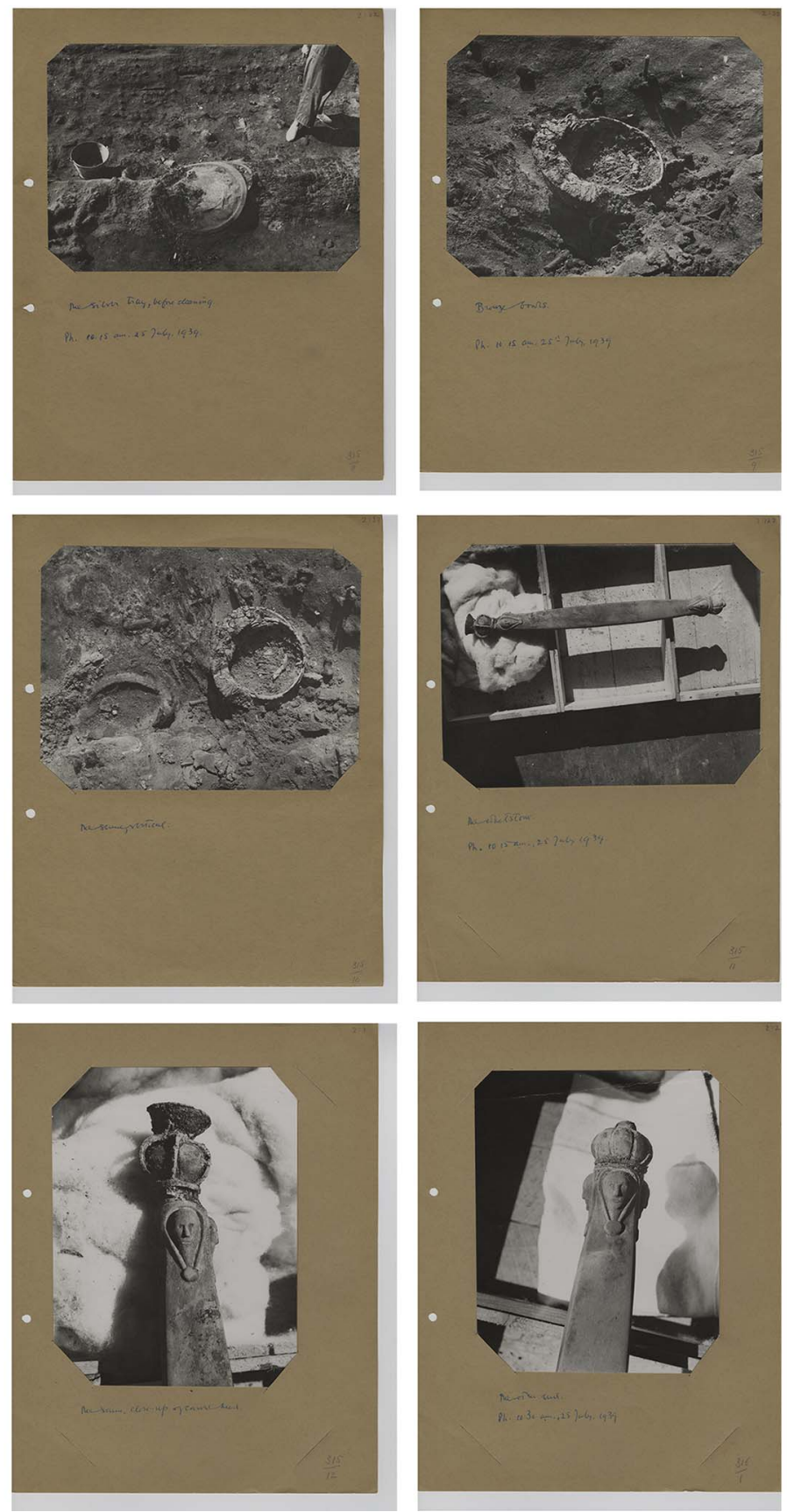

Figure 3. The first six photographs taken by Crawford (prints 2.22, 2.98, 2.97, 2.127, 2.1 \& 2.2).

off to take three photographs of the whetstone, already safely nested in a packing crate (Figure 3). This frantic dash between finds took just under fifteen minutes, an average of two minutes per photograph. The sprint between objects tells a very human story of (C) Antiquity Publications Ltd, 2019 


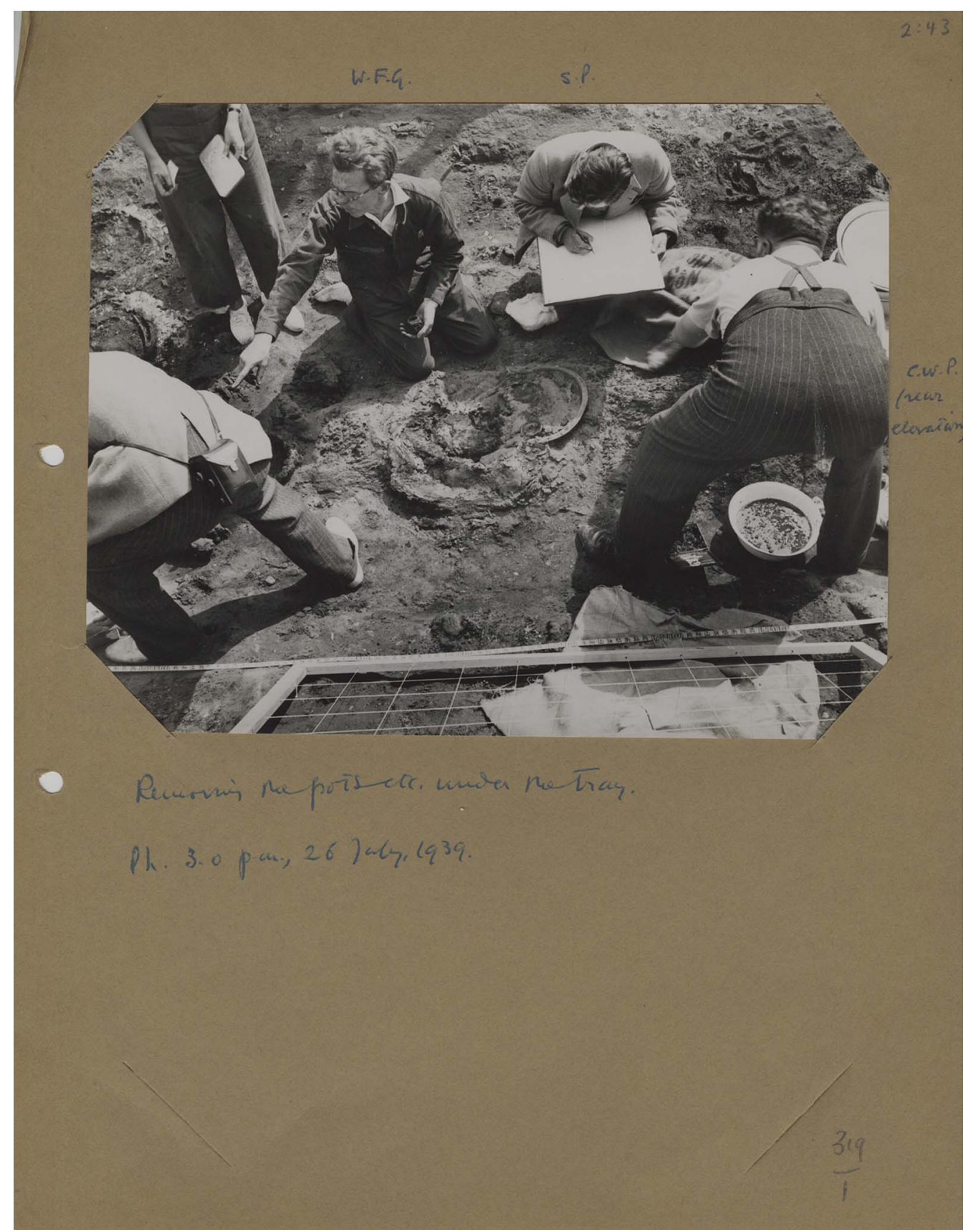

Figure 4. Rear elevation (print 2.43).

unbridled excitement. That Crawford incorporated photography into this race between the finds, rather than first touring the site and then returning to photograph at a more leisurely pace, is suggestive of how deeply ingrained photography was in Crawford's response to the excavation. 


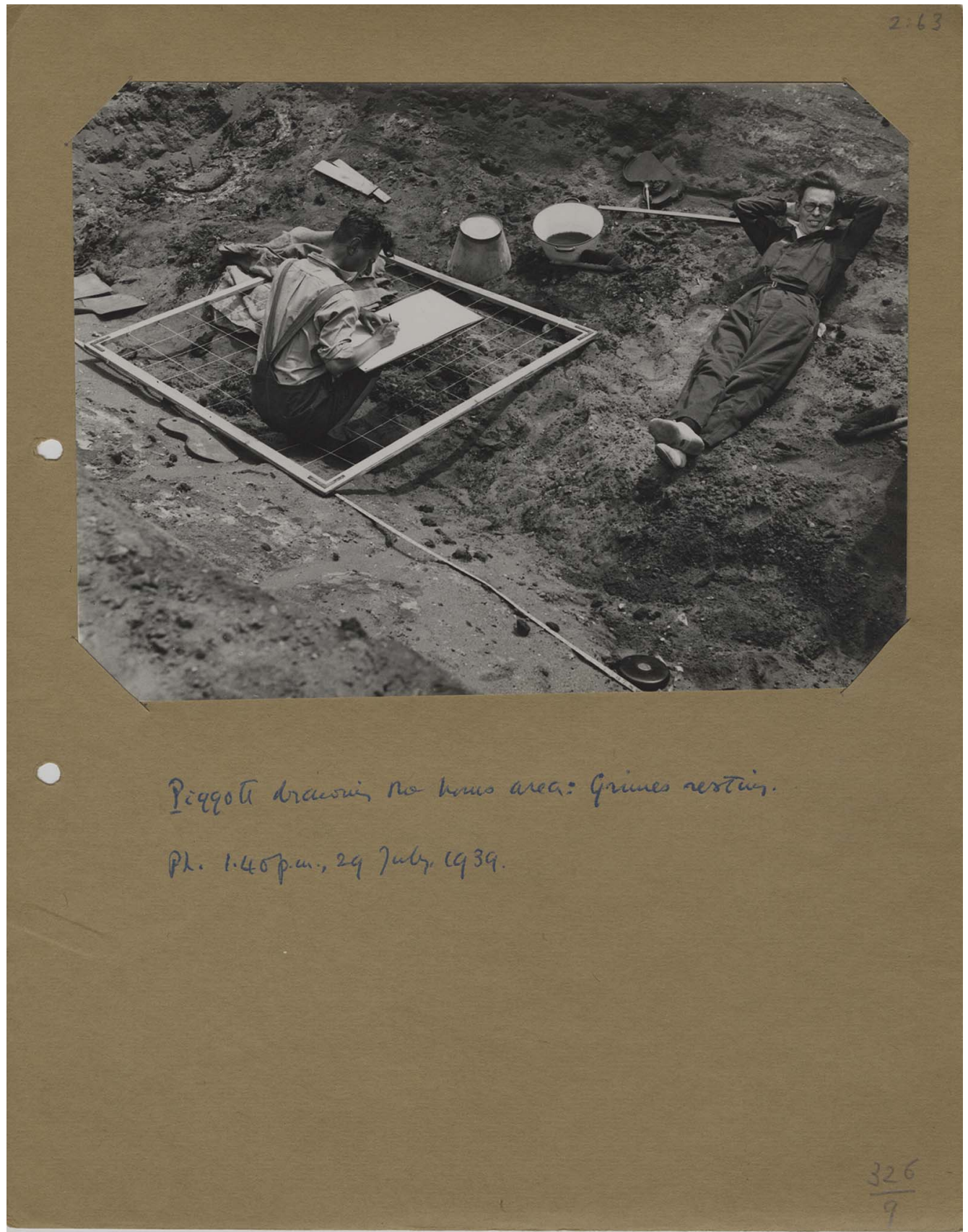

Figure 5. Grimes relaxing (print 2.63).

\section{Social traces}

It is not only in photographs of the finds that Crawford's presence behind the camera can be detected. Crawford regularly flouted developing conventions for archaeological (C) Antiquity Publications Ltd, 2019 


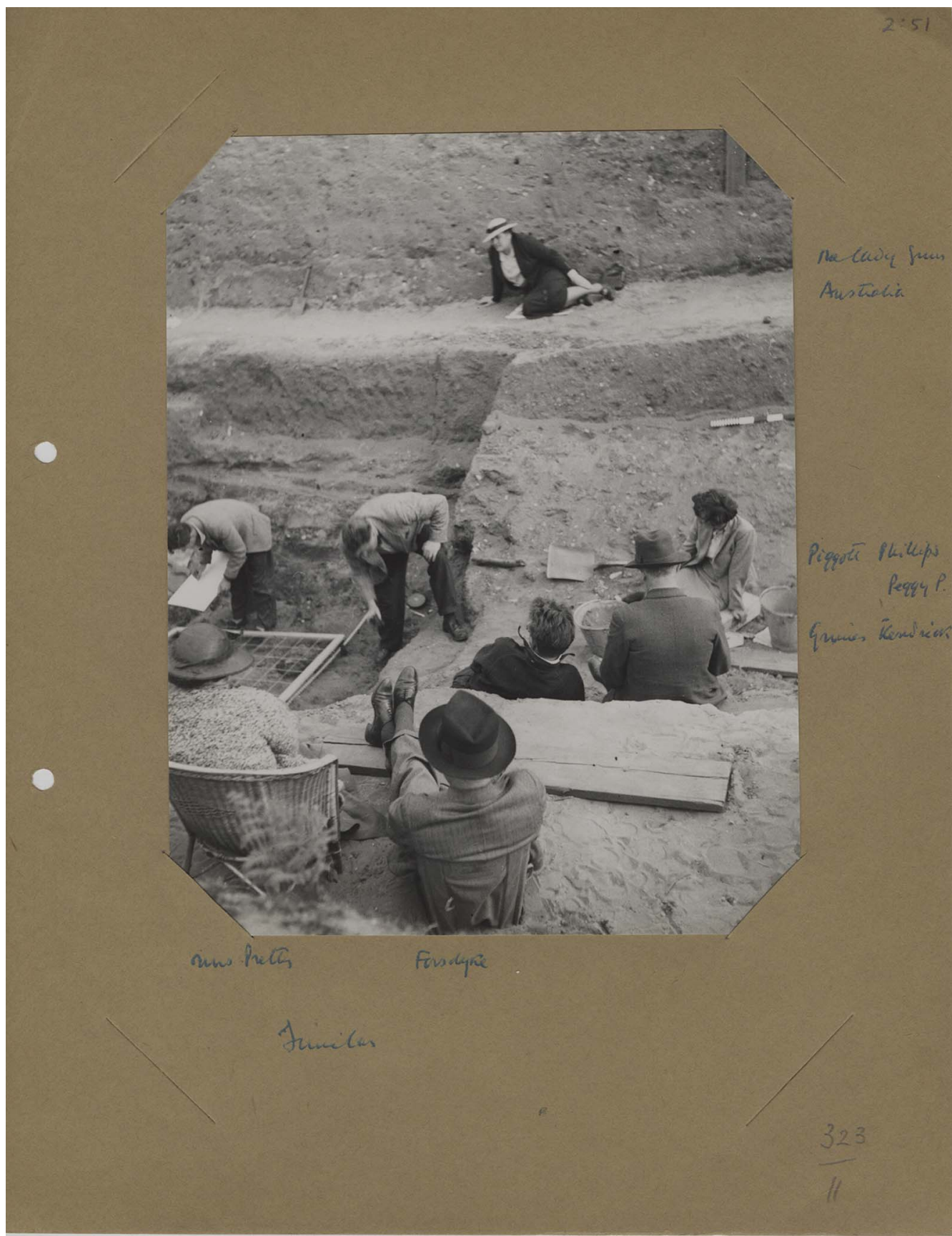

Figure 6. Social space at Sutton Hoo. This is also a photograph worthy of comment for the higher than normal ratio of women to men. Peggy Piggott is on the far right. Edith Pretty sits in the wicker chair in the foreground, while the lady from Australia' reclines on the far side of the trench (print 2.51). 
photography, which prescribed that human figures should only appear in front of the camera as a means of gauging scale (Cookson 1954: 44; Wheeler 1954: 202). Of Crawford's 124 photographs of Sutton Hoo, 43 depict archaeologists and other onlookers. These are a series of striking portraits of the excavators with whom Crawford had close personal ties. Indeed, aside from the Anastasius Dish, Crawford's colleague from the Ordnance Survey, W.F. Grimes, is the most frequent subject of Crawford's photographs of the site. Crawford's close associations with his subjects are most apparent on occasions where his annotations of the prints take a humorous turn; as in the case of print 2.43 where Crawford draws attention to Charles Phillips's "rear elevation" (Figure 4). Nor does Crawford depict archaeological labour alone. In print 2.63 Grimes lounges on the floor while Stuart Piggott draws (Figure 5). In 2.51 the proportion of seated figures to those standing makes it clear that Crawford's focus is on the activity taking place outside the burial chamber (Figure 6). Both the wide sandy platform, occupied by Peggy Piggott, Grimes and T.D. Kendrick, and the walkways along the edge of the main trench were liminal spaces simultaneously providing access points into the chamber, and a social space where those present could gather when not working.

\section{Conclusions}

These photographs of archaeologists at both labour and leisure are far removed from the scientific detachment described by Bohrer and Ingold. Rather these prints speak of much messier realities of life and provide a vital, engaging vision of archaeology in the field. Whether photographing objects or people, Crawford's photographs are gleeful, and at times irreverent. The camera is put to light-hearted, even downright humorous use, as much as it is utilised for more studious purposes. Although Crawford may not appear in front of the camera, it is vital to remember that he was both present and participating in the social interactions on the site, and that his enmeshment in the social landscape of Sutton Hoo had clear implications for the way in which he recorded the excavation. If the presence of Crawford as a photographer cannot be found in his photographs, this is more a reflection of strategies of looking at photographs, the questions asked of them and the work that they are expected to perform within institutional contexts than any inherent absence in the photographs themselves. By returning to the archive, with an awareness of what Morton (2009) has termed a "whole archive" approach, it is possible to excavate Crawford's presence at the site.

\section{Acknowledgements}

All photographs are from the Crawford Photographic Archive and appear courtesy of the Institute of Archaeology, Oxford. I would like to thank Martyn Barber, Jaanika Vider, Lesley McFadyen and Jennifer Baird for their comments on drafts of this article. This project was funded by the AHRC Collaborative Doctoral Partnership. 


\section{References}

BAIRD, J.A. 2017. Framing the past: situating the archaeological in photographs. Journal of Latin American Cultural Studies 26: 165-86. https://doi.org/10.1080/13569325.2017. 1309315

Bohrer, F.N. 2011. Photography and archaeology. London: Reaktion.

Bruce-Mitford, R.L.S. 1975. The Sutton Hoo ship-burial. London: British Museum Publications for the Trustees of the British Museum.

Cookson, M.B. 1954. Photography for archaeologists. London: Parrish.

Crawford, O.G.S. 1940. Editorial notes. Antiquity 14: $1-5$. https://doi.org/10.1017/S0003598X00014733

INGOLD, T. 2011. Being alive: essays on movement, knowledge and description. London: Routledge. https://doi.org/10.4324/9780203818336

LuCAS, G. 2001. Critical approaches to fieldwork: contemporary and historical archaeological practice. London: Routledge. https://doi.org/10.4324/9780203132258

McFadyen, L. 1997. Body imagery. Unpublished MA dissertation, University of Southampton.
McFadyen, L. et al. 1997. Gossiping on people's bodies. Unpublished Conference Paper presented at TAG 1997, Bournemouth.

Morton, C. 2009. Fieldwork and the participant-photographer: E.E. Evans-Pritchard and the Nuer Rite of Gorot. Visual Anthropology 22: $252-74$.

https://doi.org/10.1080/08949460903004896

Preston, J. 2007. The Dig. London: Viking.

RigGs, C. 2017. Shouldering the past: photography, archaeology, and collective effort at the tomb of Tutankhamun. History of Science 55: 336-63. https://doi.org/10.1177/0073275316676282

Shepherd, N. 2003. 'When the hand that holds the trowel is black...': disciplinary practices of self-representation and the issue of 'native' labour in archaeology. Journal of Social Archaeology 3: 334-52. https://doi.org/10.1177/14696053030033003

The Telegraph. 2011. Unseen photographs of 1939 excavation of Sutton Hoo discovered. Available at: https://www.telegraph.co.uk/news/uknews/ 8292937/Unseen-photographs-of-1939excavation-of-Sutton-Hoo-discovered.html (accessed 24 June 2019).

WheELER, M. 1954. Archaeology from the earth. Oxford: Clarendon.

Received: 15 April 2019; Revised: 20 June 2019; Accepted: 21 June 2019 